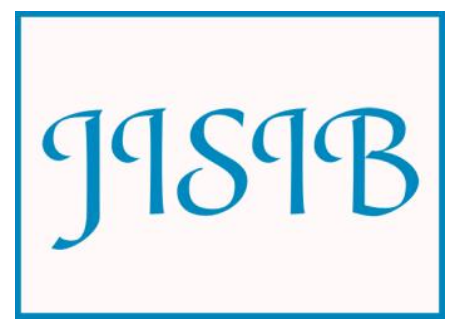

Available for free online at https://ojs.hh.se/

Journal of Intelligence Studies in Business 3 (2012) 48-54

\title{
Factors shaping vendor differentiation in the Business Intelligence software industry
}

\author{
Klaus Solberg Søilen*, Anders Hasslinger \\ **(Corresponding author), Halmstad University, Sweden \\ klasol@hh.se
}

Revised version accepted December 52012

\begin{abstract}
This paper is investigating, through a mixed-method research combining interviews and an online survey, how BI vendors differentiate themselves when it comes to application integration, security issues and pricing strategies. The conclusion is that BI vendors differentiated themselves mainly by having individual definitions of what $\mathrm{BI}$ is. Buyers are therefore advised to compare vendors through the vendor's definition of Business Intelligence. Security issues were mainly user centric and pricing strategies implied that vendors approach buyers in a similar way where they offered standardized software bundles that would require some degree of customization in order for the buyer to derive the maximum benefit from the applications. It can be deduced from the obtained results that most competitive BI vendors are acting more homogenous towards buyers when they offer their products and handle customers, compared to niche BI vendors.
\end{abstract}

KEYWORDS: Business Intelligence, Software production, Application Integration, Pricing Strategies, Security Issues, Definitions

\section{Introduction}

Making the right decisions has always been the major concern in the strategic field. Businesses are constantly under pressure to make the right decisions. Having the right information timely at hand is crucial for maintaining a competitive position in the market. In this paper we study Business Intelligence (BI) vendors. The core of the study focuses on vendor differentiation, although implications may be drawn for clients. Furthermore, as most of the larger vendors cover a huge area of soft- and sometimes even hardware applications, as well as associated products, it is difficult to overlook these aspects and solely focus on BI. Business Intelligence is a discipline which overlaps with other subjects such as Business Performance Management (BPM), Customer Relation Management (CRM), Decision Support Systems (DSS) and Knowledge Management (KM).

The overall objective of this paper is to account for how vendors chose to differentiate themselves in what has evolved into a homogenous business environment. The focus of the industry lies in distinguishable differentiation in terms of pricing 
strategies, application integration and security issues. This paper does not intend to identify the individual differentiation strategies of single vendors. The aim is rather to generalize the findings across the BI market.

\section{Method}

Data collection in this research is conducted partly through one deep interview with Oracle, followed by eight completed online-questionnaire from vendors.

The questions asked in the interview are the same as in the questionnaire, but leave more room for discussion and depth. The interview was possible, using a digital recording device. Hence, the data collected through the online-questionnaire and the interview is considered to be primary sources of data. Secondary sources of information for this study come in form of books and journals.

The BI vendors that were included in the research are presented below:

\begin{tabular}{|c|c|c|c|}
\hline Vendor & Participant & Country & Method \\
\hline Oracle & $\begin{array}{l}\text { Director BI Sales } \\
\text { Consulting EMEA }\end{array}$ & GER & Interview \\
\hline SAP & $\begin{array}{l}\text { Product } \\
\text { Management }\end{array}$ & GER & $\begin{array}{l}\text { Online } \\
\text { Survey }\end{array}$ \\
\hline $\begin{array}{l}\text { Micro } \\
\text { Strategy }\end{array}$ & $\begin{array}{l}\text { EMEA Marketing } \\
\text { Director }\end{array}$ & USA & $\begin{array}{l}\text { Online } \\
\text { Survey }\end{array}$ \\
\hline TIBCO & $\begin{array}{l}\text { European Manager, } \\
\text { Technical Sales }\end{array}$ & USA & $\begin{array}{l}\text { Online } \\
\text { Survey }\end{array}$ \\
\hline $\begin{array}{l}\text { Traction } \\
\text { Software }\end{array}$ & $\begin{array}{l}\text { President and Co- } \\
\text { founder }\end{array}$ & USA & $\begin{array}{l}\text { Online } \\
\text { Survey }\end{array}$ \\
\hline Astragy & Marketing Director & NED & $\begin{array}{l}\text { Online } \\
\text { Survey }\end{array}$ \\
\hline $\begin{array}{l}\text { SAS } \\
\text { Institute }\end{array}$ & Academic Sale & SWE & $\begin{array}{l}\text { Online } \\
\text { Survey }\end{array}$ \\
\hline QlikTech & Country Manager & SWE & $\begin{array}{l}\text { Online } \\
\text { Survey }\end{array}$ \\
\hline Microsoft & $\begin{array}{l}\text { Marketing Manager } \\
\text { BI }\end{array}$ & SWE & $\begin{array}{l}\text { Online } \\
\text { Survey }\end{array}$ \\
\hline
\end{tabular}

Table 1: List of Participants

The statistical population was defined as a result of an internet based research on Business Intelligence vendors. The Magic Quadrant for Business Intelligence Platforms report issued by Gartner Inc., an American based IT research and advisory firm, also provide insights into the BI market to give an idea of which vendors are relevant. The program used to create the questionnaire was eVal.

The research questions will provide answers to the title and are limited within the context. They are as follows:
Q1. How versatile in respect to data exchange and integration are BI products today?

Q2. What are the major information security issues associated with BI products today?

Q3. How do BI vendors chose to differentiate themselves from their main competitors?

Q4. What pricing strategy do BI vendors pursue?

Q5. What are the main reasons for customer rejection?

Q6. What clients, servers and databases does the BI platform support?

Q7. How importantly do vendors view customer needs for a complete solution?

Q8. Where do BI vendors see their competitive advantage?

Q9. Where do BI vendors see their future opportunities and threats?

\section{Theory and problem discussion}

According to Howson [2008] Business Intelligence is a set of technologies and processes that allow people at all levels of an organization to access and analyze data. Loshin [2003] uses the definition of The Data Warehousing Institute to define BI as "The process, technologies, and tools needed to turn data into information, information into knowledge, and knowledge into plans that drive profitable business action. Business Intelligence encompasses data warehousing, business analytic tools, and content/knowledge management." [Loshin 2003, 6].

Business Intelligence may however be defined in many ways. Often vendors "craft" their own definition to show their tools in the best possible light [Langit 2007]. There are often not only different definitions of BI, but different terms are used to describe Business Intelligence. Thus BI is often wrongly referred to as Competitive Intelligence (CI), Business Performance Management (BPM), Executive Information Systems (EIS), Management Information Systems (MIS), Business Information System (BIS) or Decision Support System (DSS), just to name a few of the more common forms.

It is vital to distinguish between the differences in terminologies. E.g. according to Clifton and Sutcliffe [1990], DSS support the decision-making process and is most effective at calculating risk, as for example probability situations, where the manager is faced with a number of alternative choices. DSS enables managers to retrieve information ad hoc and as straightforwardly as possible in order to facilitate decision-making.

Executive Information Systems (EIS) are a function of a DSS, as they provide decision support to management, with information retrieval powerful display capabilities for business graphics, and communications. Thus the term EIS may be 
seen as an old fashioned term to describe today's digital dashboards, which are also often described under Management Information Systems (MIS).

An Enterprise Resource Planning (ERP) system could be described as the backbone and perhaps basic IT system in an organization. The creation of ERP-systems integrates all the functional areas of an organization. Although ERP-systems can integrate all business transaction data, it is not a system for data analysis. These transactional systems, however, do not meet management's needs to discover trends and patterns for performing optimized and effective decisionmaking. ERP-systems are designed to record and manage business transaction data. If BI and ERP are integrated, they contribute with additional value to the organization, which may be used to enhance ERP-systems. In contrast, analytical BI systems are designed to examine large volumes of data as a foundation for decision-making [Chou, Tripuramallu, \& Chou 2005].

Business Performance Management (BPM), also known as Enterprise Performance Management (EPM), is a framework for automating, organizing, and analyzing business processes and systems that drive business performance to achieve maximum value [Blansfield 2003]. Indart [2006] concludes that performance management solutions are more process-orientated. Lee \& Dale [1998] conclude that BPM could be considered a customer-focused approach to the systematic management, measurement and improvement of all company processes through cross-functional teamwork and employee empowerment. Bose [2005] claims that BPM is a combination of planning, budgeting, financial consolidation, reporting, strategy planning and business scorecard tools. Specifically, BPM helps operational BI decision making become more proactive and timely, and support a wide range of business users [Ballard et al. 2005]. Therefore with regards to the analytical capabilities, one could argue that BI is a part of BPM. As Bose [2005] points out, Menninger concluded that "most vendors do not offer the full set of these components, so they adjust their version of the definition to suit their own product set" [Bose $2005,50]$. It could also be argued that MBP is so wide a term it risks to become equivalent to terms like Management, which at the end can come to mean all that managers do within the private organization. An overview of the definitions is presented below:

\begin{tabular}{|l|l|l|}
\hline Abbr. & Term & Definition \\
\hline BI & $\begin{array}{l}\text { Business } \\
\text { Intelligence }\end{array}$ & $\begin{array}{l}\text { A umbrella term referring } \\
\text { to the technical side within } \\
\text { private intelligence and } \\
\text { the process of collecting, } \\
\text { processing, analyzing and }\end{array}$ \\
\hline
\end{tabular}

\begin{tabular}{|c|c|c|}
\hline & & disseminating intelligence \\
\hline BPM & $\begin{array}{l}\text { Business } \\
\text { Performance } \\
\text { Management }\end{array}$ & $\begin{array}{l}\text { A framework for } \\
\text { automating, organizing, } \\
\text { and analyzing business } \\
\text { processes and systems that } \\
\text { drive business } \\
\text { performance to achieve } \\
\text { maximum value }\end{array}$ \\
\hline $\mathrm{CI}$ & $\begin{array}{l}\text { Competitive } \\
\text { Intelligence }\end{array}$ & $\begin{array}{l}\text { A umbrella term referring } \\
\text { to the managerial side of } \\
\text { private intelligence }\end{array}$ \\
\hline DSS & $\begin{array}{l}\text { Decision } \\
\text { Support } \\
\text { System }\end{array}$ & $\begin{array}{l}\text { Computer- } \\
\text { based information } \\
\text { systems that } \\
\text { support decision- } \\
\text { making activities by } \\
\text { presenting alternative } \\
\text { choices }\end{array}$ \\
\hline EIS & $\begin{array}{l}\text { Executive } \\
\text { Information } \\
\text { System }\end{array}$ & $\begin{array}{l}\text { Computer-based } \\
\text { information system } \\
\text { providing easy access to } \\
\text { both internal and external } \\
\text { information relevant to } \\
\text { meeting the strategic goals } \\
\text { of the organization on a } \\
\text { graphical user interface. } \\
\text { Sometimes referred to as } \\
\text { to digital dashboards }\end{array}$ \\
\hline EPM & $\begin{array}{l}\text { Enterprise } \\
\text { Performance } \\
\text { Management }\end{array}$ & See BPM \\
\hline ERP & $\begin{array}{l}\text { Enterprise } \\
\text { Resource } \\
\text { Planning }\end{array}$ & $\begin{array}{l}\text { Enterprise-wide } \\
\text { information system } \\
\text { designed to coordinate all } \\
\text { the resources, information, } \\
\text { and activities needed to } \\
\text { complete business } \\
\text { processes such as order } \\
\text { fulfillment or billing. }\end{array}$ \\
\hline
\end{tabular}

Table 2: List of Definitions

The two most related terms are BI and CI. Defining the differences between $\mathrm{BI}$ and $\mathrm{CI}$ has caused considerable debates between practitioners and academics [Wright \& Calof 2006]. The term has become clearer now that the impact of the technology side has become more evident. E.g. Solberg Søilen [2005] points out that Business Intelligence now relates to the technical side whilst Competitive Intelligence relates to the managerial side within private intelligence. A logic overview of the most important terms is presented in a Venn diagram below (white background indicates IT based): 
Figure 1: Logic of Terms

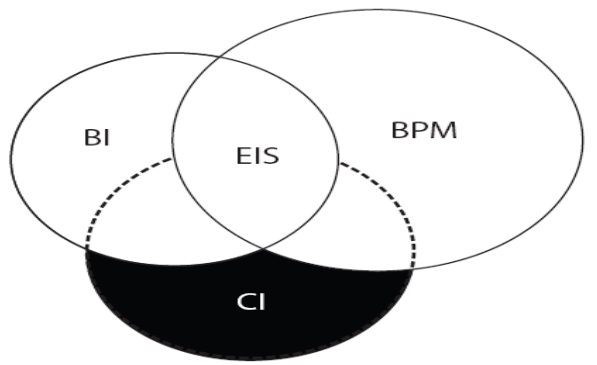

Another question which often arises is about Knowledge Management (KM) and how it should be treated in respect to BI. Knowledge Management deals with the process of creating value from an organization's intangible assets [Liebowitz 1999]. BI has more practical problem solving features, whilst KM encompasses the realization and preservation of knowledge. Solberg Søilen [2005] argues that all subjects dealing with information and knowledge may be gathered under the term Information Management. Marketing is also an area into which BI often finds its way, especially when gathering data about customers such as through CRM. At the end what should decide what term is used for each study or specialization is if it can be clearly defined and thereafter its usefulness.

\section{Critical differentiations defined}

\subsection{Application Integration}

Within the context of enterprise systems, there is no single definition what integration entails. General consensus lays within the description that integration makes applications work together that "were not intended to work together by passing information through some form of interface" [Gulledge 2006, 5]. Companies that implement a BI solution often have an existing ERP-system from which they obtain the transactional data which is used for analysis. It automatically becomes an important issue how well the systems work together. Howson [2008] states that, historically, companies had to buy multiple BI front-end tools from different vendors, because no single vendors offered the full spectrum of tools. According to Howson [2008], as an example Microsoft Office Excel is sometimes referred to as the leading BI tool for creating spreadsheets. Hence, the importance of offering integration to applications such as the Microsoft Office Series or similar products with widespread usage.

From a customer's point of view BI projects should be funded based on a projected Return-onInvestment (ROI) [Hedgebeth 2007]. On the other hand, Fuld [1991] argue that companies should not make an intelligence program a strict ROI issue. Yet, BI is often ROI driven. Companies that implemented ERP solutions and that were unable to justify ROI for ERP implementation, were sometimes implementing BI software since BI enhanced the utilization of the enterprise data [Chou et al. 2005].

\subsection{Security}

There are several threats to computer security which of course influence the security of BI systems. Sanderson and Forcht [1996] show that there are a number of intruders that poses threats for a number of different reasons. Examples are foreign intelligence services, organized crime, terrorist organizations, industrial espionage agents, private investigators, and information brokers who illegally sell information as well as hackers. Security threats to system structures are constantly being added as the overlapping of computers, resources and industries, referred to as convergence, integrates IT infrastructures to provide more customers through established lines. Sanderson and Forcht [1996] argue that, "threats to companies through convergence have a great range" [Sanderson \& Forcht 1996, 33], involving anything from fraud, unauthorized disclosure of information, and unauthorized modification of sensitive information, to information brokering.

Computer fraud and abuse may involve the accessing of computers without authorization or exceeding that authorization to perform malicious acts against computing resources. Generally regarded as the biggest threat to an organization's information resources, however, are insiders employees and others in trusted positions with an organization that have great access to information within the organization [Denning 1999].

Regarding BI, there are typically two major security areas discussed in the literature: role-based access and Internet security. The first deals directly with the employees and the second more generally with computing. The two terms role-based access and Internet security are explained with greater detail below.

The weakest spot in a BI system may also vary. The information in OLAP structures is often very sensitive. The sensitivity can range from highly confidential internal data to data that has a high level of intellectual capital investment [Rasmussen et al. 2002]. However, IT security in general and BI security, are much broader topics than what has been suggested here.

Role-based security usually has roles defined for different levels of responsibility within an organization. Rasmussen et al. [2002] describe role-based access as associating a user ID with a role which has certain restrictions for information 
visibility. Employees that fall into certain areas of responsibility then become members of those roles.

Vendors often offer two types of licenses: named-user licenses and concurrent licenses. Named-user licenses are purchased and assigned to specific end-users, whilst the concurrent user licensing structure provides a specific number of licenses that may be shared amongst a group of users [Bontis \& Chung 2000]. For example, a business with two concurrent licenses to an application that are set to three workstations can have two employees using the application simultaneously. A third user is not allowed and has to wait until one of the two users logs-off. Some vendors also offer different classes of users, for example a standard user and a light user license. The standard user is given full application access, whilst the light user is given a restricted set of features [Bontis \& Chung 2000].

It may also be a great advantage to businesses making BI information available to its employees across the internet. It may range from information that is running on a secure connection to information that businesses wish to make public. The advantage of using the internet is that it offloads all the infrastructural responsibilities of an IT department, which could stand for significant savings. The downside is associated with security issues as the growing success of the Internet, make it easier to invade corporate privacy [Wright \& Roy 1999].

\subsection{Pricing Strategy}

In terms of B2B software pricing strategies, there is not a single perfect generic pricing model. In a case study, Bontis and Chung [2000] conclude that "vendors must understand the value they provide to customers and create a price structure that aligns pricing with value realization, but more importantly facilitates their business objectives of the product and service." [Brontis \& Chung 2000, 246]. Thus, it depends on the need of the buyer that vendors align pricing with the buyers product goals.

Originally, as software ran on mainframes, it was priced according to CPU speed. This pricing method, based on processing usage, did not consider the needs of neither buyers nor vendors [Bontis \& Chung, 2000]. As software architectures evolved through time, pricing models moved towards named and concurrent user licenses. Named-user licenses are purchased and assigned to specific end-users, whilst the concurrent user licensing structure provides a specific number of licenses that may be shared amongst a group of users. Bontis and Chung [2000] explain that the price structures, associated with concurrent licenses, charge customers according to their peak user predictions. A software vendor is, therefore, looking for both revenue maximization as well as market share as concurrent licenses are accessibly from a corporate site.

Additionally the license time is of importance. The possibility to offer a perpetual license, that is one that continues indefinitely [Bennet \& Kosc 2002], or a term license, one which is limited in time and can be renewed are important and common possibilities for vendors to charge its buyers. Other possibilities are for example rental or leasing, where there are no boundaries set to the payment or pricing options. Hence, as concluded by Bontis and Chung [2000], software development is an output of a programmer's intellectual capital, the pricing of software often requires a more subjective approach.

A recent study [PricewaterhouseCoopers 2008] shows that software vendor revenues are shifting from license fees to maintenance fees. The study explains that a consistent trend is the transition from large perpetual licenses to alternative models that stretch payments over a period of time. Other vendors are finding greater success by generating more revenue from maintenance and support instead.

Another trend that has emerged within the software industry are Software-as-a-Service (SaaS) solutions. SaaS is web-based software which is purchased on subscription basis and allows an organization to shift almost all their technological responsibility to the vendor [Lashar 2008].

The SaaS model is an objective pricing model based on transactions volume and usage. The adoption of a SaaS model, however, eliminates most of the challenges that occur with product installation and allows firms to optimize their resource allocation. [Bhingarde et al. 2008]

Lashar [2008] also states that SaaS can be a compelling option especially for larger business if the need for standardization, data centralization and BI exists as opposed to the need for differentiated functionality within the organization or specialized functionality; in which case, SaaS would not be an option.

\section{Results}

The overall objective of the paper was to account for how vendors chose to differentiate themselves in terms of pricing strategies, application integration and security issues. Nine research questions were set of which eight could be answered. One research question could only be answered partially, but is viewed upon as not answered.

The study collected data from a BI vendor population that what was set to one deep interview and 27 vendor questionnaires. Out of these 27 a total of 9 vendors completed the questionnaire, which can be said to have been expected given that no financial remuneration was offered. 
The areas of application integration (Q1), security issues (Q2) and pricing strategy (Q4) can be summarized within this research to the BI market as that application integrated easily. The research question, what clients, servers and databases does the BI platform support (Q6), could only be answered incomplete. The reason for this is that the received answers could not be organized to support any general conclusions. Due to the way the question was phrased, the research question remains unanswered. Security issues (Q2) were mainly user centric and pricing strategies (Q4) implied that vendors approach buyers in a similar way where they offered standardized software bundles that could require some degree of customization in order for the buyer to derive the maximum benefit from the applications. It can be deduced from the obtained results that the most competitive BI vendors are acting more homogenous towards the buyers in the way they offer their products and handle customers, compared to niche BI vendors.

One implication that can be drawn for buyers from the obtained results is that buyers should carefully look at what they want to do with a BI system and find a vendor that has a definition of BI similar to the buyer's vision.

More importantly BI vendors chose mainly to differentiate themselves (Q3) through their individual definition of how they define BI, as also stated by Howson [2008], to create a definition that best suits their products. We could call this the Selling Theory of the Business Intelligence label, even though I am sure it related to many other forms of software and services as well. Hopefully a clearer difference as to the meaning of the terms used, as suggested in the table and the Venn model above, can help avoid this problem in the future.

There was no clear reason to why potential customers, such as customers that are in negotiations with several vendors, would reject (Q5) a vendor. One reason was that the vendor perhaps did not fulfill the client's needs, but not what the underlying reasons were. Due to the received answers, it can be said within this context, that vendors generally did not know the specific reasons.

Most vendors saw that their competitive advantage (Q8) was that they were able to offer the customer a complete BI solution (Q7) within the entire spectrum of BI applications, or that they were focusing on niche areas such as Traction Software. Not many vendors chose to answer the question where they saw their future opportunities and threats (Q9). Those that did, however, delivered some interesting market insights. The bigger BI vendors clearly saw their advantage in working with the full spectrum of BI tools and possibilities. Most vendors did not see any threats, or at least did not state them. One stated that it did not see any threats, but rather opportunities, whilst another feared low-end competition from generic tools such as offered from Google and Microsoft. Most opportunities were seen in making BI available across an entire company and thereby moving more towards operational BI. Oracle saw huge opportunities for BI for the future as the demand for decision making based on intelligence obtained from data is increasing. Further Oracle points out the possibilities that are emerging within RFID. Regulatory changes make it possible for data to be stored even longer and be used for analytics. TIBCO saw opportunities within pervasive BI, by optimizing today's BI environment and responding to the emerging demand from this convergence to make decision making available in real-time within the right context to any specific business process. Traction Software looks towards a Web 2.0-style integration with ERP software, in the context of product development and manufacturing, with BI through human analysis, dissemination and issue tracking. Astragy saw possibilities within SaaS and SAS Institute within analytics while Microsoft expected future opportunities are to be found in making BI available to everyone within an organization.

Based on our findings we able to draw a general model containing the tree most important factors of differentiation in BI software applications:

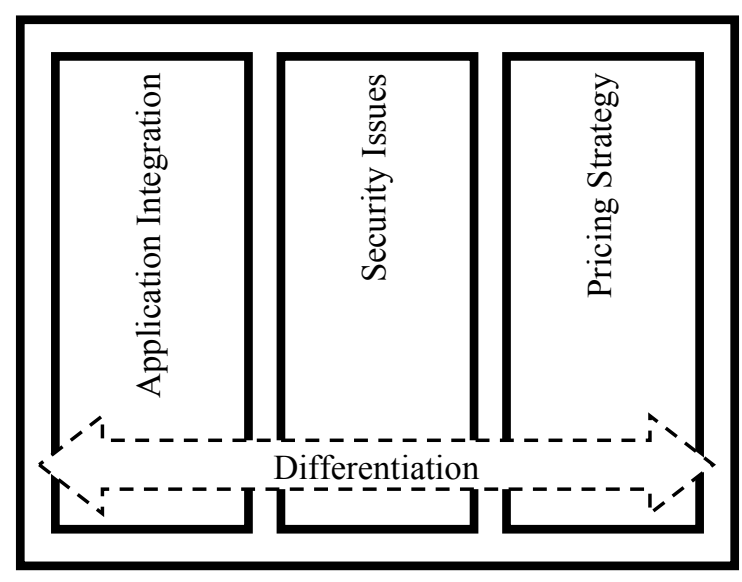

Figure 2: Contextualization of contiguity within applied field of study

\section{References}

Ballard, C., White, C., McDonald, S., Myllymaki, J., McDowell, S., Goerlich, O., et al. (2005). Business Performance Management...Meets Business Intelligence. North Castle Drive Armonk: IBM Redbooks.

Bennet, M. P., \& Kosc, J. (2002). The Basics of Software Licensing. Journal of Investment Compliance, Vol. 2, No. 4, pp. 18-29. 
Bhingarde, N., Arora, H., \& Simon, E. (2008). SaaS and Corporate Actions. Wall Street \& Technology, Vol. 26, No.1, p. 36.

Blansfield, D. (2003). A New Urgency. Business Performance Management, pp. 4-5.

Bontis, N., \& Chung, H. (2000). The evolution of software pricing: from box licenses to application service provider models. Internet Research: Electronic Networking Applications and Policy, Vol. 10 No. 3, pp. 246-255.

Bose, R. (2006). Understanding management data systems for enterprise performance management. Industrial Management \& Data Systems, Vol. 106 No. 1, pp. 43-59.

Chou, D. C., Tripuramallu, H. B., \& Chou, A. Y. (2005). BI and ERP integration. Information Management \& Computer Security, Vol. 13 No. 5, pp. 340-349.

Clifton, H. D., \& Sutcliffe, A. G. (1990). Business Information Systems. Hemel Hempstead, Hertfordshire, UK: Prentice Hall.

Denning, D. E. (1999). Information Warfare and Security. Addison-Wesley: New York.

Fuld, L. (1991). A Receipe for Business Intelligence Success. The Journal of Business Strategy, pp. 12-18.

Gulledge, T. (2006). What is integration? Industrial Management \& Data Systems, Vol. 106 No.1, pp. 5-20.

Hedgebeth, D. (2007). Data-driven decision making for the enterprise: an overview of business intelligence applications. VINE: The journal of information and knowledge management systems, Vol. 37 No. 4, pp. 414420.

Howson, C. (2008). Successful Business Intelligence - Secrets to Making BI a Killer App. Columbus, OH: McGraw-Hill.

Indart, B. (2006). Operationalizing Business Intelligence - Turning Insight into Action. Business Intelligence Journal, Vol. 11 No. 2, pp. 35-38.

Langit, L. (2007). Foundations of SQL Server 2005 Business Intelligence. Berkeley, CA: Apress.

Lashar, D. J. (2008). Are You Ready for SaaS? Customer Relationship Management, Vol. 12, No. 2, pp. 12.

Lee, R. G., \& Dale, B. G. (1998). Business process management: a review and evaluation. Business Process Management Journal, Vol. 4 No. 3, pp. 214-225.

Liebowitz, J. (1999). Knowledge Management Handbook. Boca Raton, FL: CRC Press LLC.

Loshin, D. (2003). Business Intelligence - The Savvy Manager's Guide. San Francisco: Morgan Kaufmann Publishers.

PricewaterhouseCooper (2007), Software Pricing Trends: How vendors can capitalize on the shift to new revenue models, Retrieved June 20, 2008, from http://www.pwc.com/

Rasmussen, N. H., Goldy, P. S., \& Solli, P. O. (2002). Financial Business Intelligence. New York: John Wiley \& Sons, Inc.

Sanderson, E., \& Forcht, K. A. (1996). Information security in business environments. Information Management \& Computer Security, Vol. 4, No. 1, S. pp. 32-37.

Solberg Søilen, K. (2005). Introduction to Private and Public Intelligence. Lund, Sweden: Studentlitteratur.

Wright, S., \& Calof, J. L. (2006). The quest for competitive, business and marketing intelligence. European Journal of Marketing, Vol. 40 No. 5/6, pp. 453-465. 